\title{
Hidden Archaean and Palaeoproterozoic crust in NW Ireland? Evidence from zircon Hf isotopic data from granitoid intrusions
}

\author{
M. J. FLOWERDEW*†, D. M. CHEW $\ddagger$ J. S. DALY $\&$ I. L. MILLAR \\ ${ }^{*}$ British Antarctic Survey, High Cross, Madingley Road, Cambridge, CB3 0ET, UK \\ $\ddagger$ Department of Geology, Trinity College Dublin, Dublin 2, Ireland \\ $\S U C D$ School of Geological Sciences, University College Dublin, Belfield, Dublin 4, Ireland \\ qNERC isotope Geosciences Laboratory, Kingsley Dunham Centre, Keyworth, Nottingham, NG12 5GG, UK
}

(Received 23 February 2009; accepted 21 April 2009; First published online 7 September 2009)

\begin{abstract}
The presence of major crystalline basement provinces at depth in NW Ireland is inferred from in situ Hf isotope analysis of zircons from granitoid rocks that cut structurally overlying metasedimentary rocks. Granitoids in two of these units, the Slishwood Division and the Tyrone Central Inlier, contain complex zircons with core and rim structures. In both cases, cores have average $\mathrm{EHf}$ values that differ from the average $\varepsilon \mathrm{Hf}$ values of the rims at $470 \mathrm{Ma}$ (the time of granitoid intrusion). The Hf data and similarity in $\mathrm{U}-\mathrm{Pb}$ age between the inherited cores and detrital zircons from the host metasedimentary rocks suggests local contamination during intrusion rather than transport of the grains from the source region at depth. Rims from the Slishwood Division intrusions have average $\varepsilon \mathrm{Hf}_{470}$ values of -7.7 , consistent with a derivation from juvenile Palaeoproterozoic crust, such as the Annagh Gneiss Complex or Rhinns Complex of NW Ireland, implying that the deep crust underlying the Slishwood Division is made of similar material. Rims from the Tyrone Central Inlier have extremely negative $\mathrm{EHf}_{470}$ values of approximately -39 . This isotopic signature requires an Archaean source, suggesting rocks similar to the Lewisian Complex of Scotland, or sediment derived wholly from it, occurs at depth in NW Ireland.
\end{abstract}

Keywords: zircon, Hf isotope, granite, petrogenesis, Caledonides.

\section{Introduction}

The whole rock chemistry and mineral chemistry of intrusive rocks can help fingerprint the melt source region. The mineral zircon is particularly useful as it is refractory, can survive crustal melting, can be transported from the source with the melt and new zircon can grow as the melt crystallizes (Clemens, 2003; Williams, 2001). In situ U-Pb geochronology can help determine both the age of magmatism (by analysing the zircon that represents the melt if they occur as rims) and the age of inherited zircons (by dating xenocrystic cores) from the source region (e.g. Pidgeon \& Compston, 1992). In situ Lu-Hf isotopic analysis of the dated domains can determine if the rims grown from the melt represent the same $\mathrm{Hf}$ isotopic reservoir as the Hf present in the inherited cores and grains. Similar isotopic compositions imply that the cores are relict members of the source rock zircon population, and thus cognate. Differences point to separate origins, that is, that the cores represent true xenocrysts incorporated from the wall rocks. Mantle extraction ages (model ages) can be calculated for the different zircon components, facilitating evaluation of the tectonic setting, for example, distinguishing juvenile crustal addition from reworking. Use of the $\mathrm{Hf}$ isotopic composition of zircon in this way can lead to a more sophisticated understanding of the petrogenesis than is

$\nmid$ Author for correspondence: mf@bas.ac.uk possible using the widely employed whole-rock Sm$\mathrm{Nd}$ technique (e.g. Flowerdew et al. 2006; Chen et al. 2007; Wu et al. 2007; Yang et al. 2007; Zeh et al. 2007).

In the Caledonides of NW Ireland, the crystalline basement is rarely exposed. Most of the crustal section is made up of Neoproterozoic to Palaeozoic metasediments of the Dalradian Supergroup folded into large (10 km wavelength) folds, as well as later SilurianDevonian Caledonian intrusives. Various lines of evidence suggest that the Dalradian metasediments were deposited on Palaeoproterozoic orthogneisses of the Rhinns and Annagh Gneiss complexes at the margin of Laurentia (Fig. 1). The southeastern limit of the buried edge of Laurentia is conventionally delimited by the Fair Head-Clew Bay Line (Max \& Riddihough, 1975; Fig. 1), a magnetic expression of the suture between the Midland Valley Terrane and Laurentia. The arc rocks of the Midland Valley Terrane collided with the Laurentian margin during the Early Ordovician Grampian Orogeny (Van Staal et al. 1998).

Two enigmatic bodies of quartzofeldspathic schist and paragneiss, the Tyrone Central Inlier (Hartley, 1933) and Slishwood Division (Max \& Long, 1985), are exposed close to the Laurentian margin in Ireland. Both units lie structurally beneath Dalradian rocks and both have been correlated with either the Dalradian (Sanders, 1994; Chew et al. 2008) or the Moine Supergroup (Powell, 1965), another metasedimentary unit exposed in Scotland. In view of their tectonic 


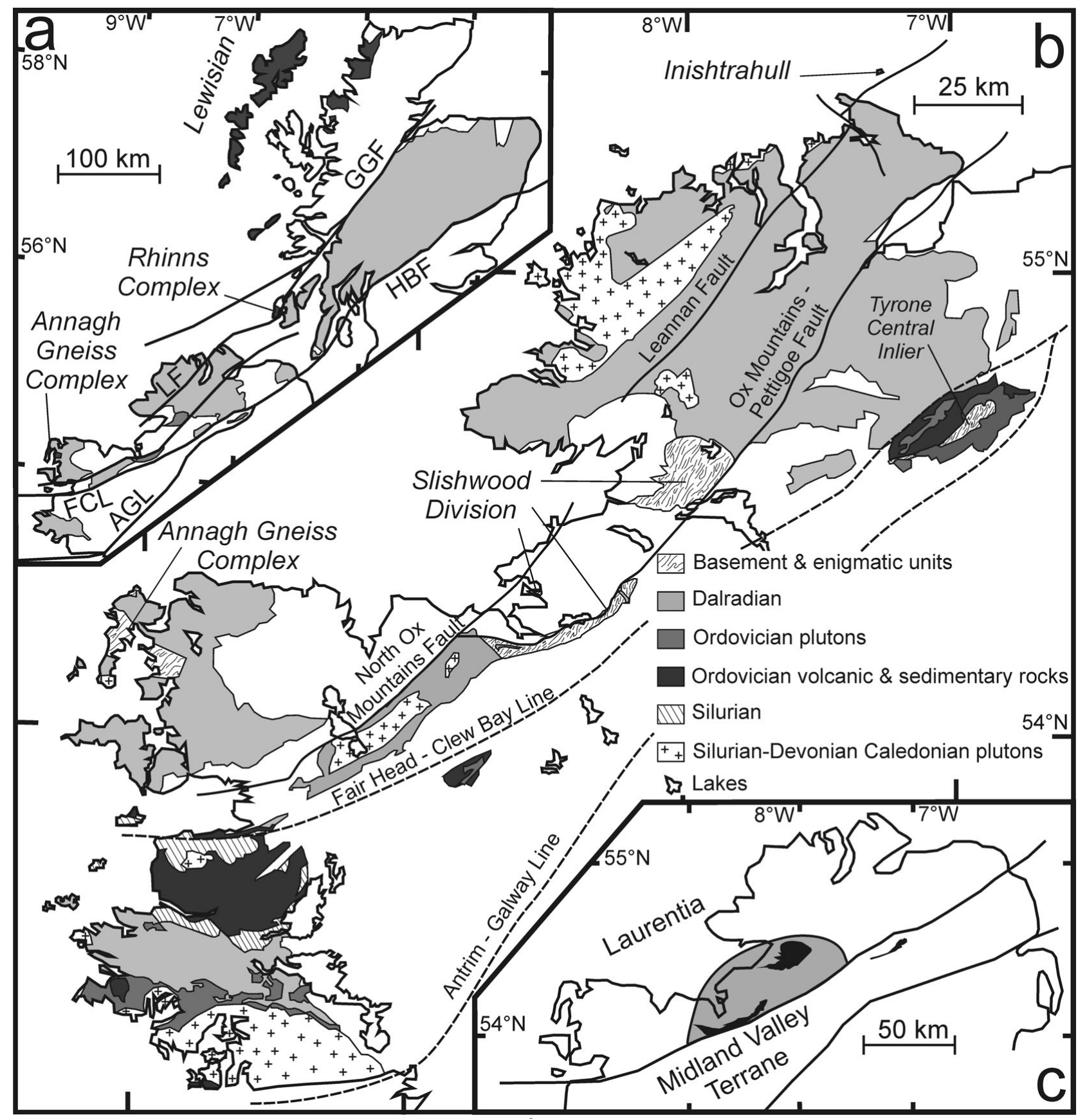

Figure 1. (a) Schematic geology of British and Irish Caledonides showing major fault lines. Dark shading: Grenvillian and older crystalline basement rocks (Lewisian, Rhinns Complex and Annagh Gneiss Complex); medium shading: Slishwood Division and Tyrone Central Inlier; pale shading: Dalradian. Bold lines are major fault lines where: AGL - Antrim-Galway Line (Ryan et al. 1995), FCL - Fair Head-Clew Bay Line, GGF - Great Glen Fault, HBF - Highland Boundary Fault and LF -Leannan Fault. (b) Schematic geology of NW Ireland. Basement includes older crystalline rocks (Rhinns Complex on Inishtrahull and Annagh Gneiss Complex, labelled) and the enigmatic units refer to the Slishwood Division and Tyrone Central Inlier (labelled). Ordovician volcanic and sedimentary rocks include those of the Midland Valley Terrane (Lough Nafooey arc, Charlestown and Tyrone Inlier), South Mayo Trough, Clew Bay Complex. Ordovician plutonic rocks are associated with Grampian Orogeny. Major faults are shown in bold; crustal structures inferred from geophysical data are dashed. (c) Map showing the distribution of the Laurentia and the Midland Valley Terrane based on geology and geophysics and the extent of the geophysical anomaly centred on the Slishwood Division (grey shading). Black areas indicate outcrop of the Slishwood Division and Tyrone Central Inlier.

position, anomalously high metamorphic grade and evidence for pre-Grampian metamorphism (Flowerdew \& Daly, 2005; Sanders, Daly \& Davies, 1987; Daly, 2009), it is possible that these units and their hidden basement were carried along with the Midland Valley Terrane arc and are exotic to Laurentia. Alternatively, they may rest on a tectonically isolated piece of Laurentia that was placed outboard of the margin during the opening of the Iapetus Ocean and was subsequently re-attached to the margin during the Grampian Orogeny (Chew et al. 2008; Flowerdew, Daly \& Whitehouse, 2005). Determining which model is correct is frustrated 
by the difficulty in dating the metamorphism affecting these units. However, the geochronology presented by Chew et al. (2008) for the Tyrone Central Inlier lends support for a Laurentian affinity and therefore the latter model is appropriate for the Tyrone Central Inlier.

Using $\mathrm{Lu}-\mathrm{Hf}$ isotopic analyses of zircons from minor Ordovician granitoid intrusions that cut the Slishwood Division and Tyrone Central Inlier, this study aims to investigate the hidden basement and to explore the tectonic implications of different basement types. Regional variations in the basement architecture would help to trace deep crustal boundaries such as that between the Annagh Gneiss Complex and Rhinns Complex in NW Ireland, which has been distinguished on $\mathrm{Pb}$ isotopic grounds by Tyrrell, Haughton \& Daly (2007). An exotic affinity for the buried crystalline basement would lend further support for the existence of preGrampian basement within the Midland Valley Terrane, which is suggested by whole-rock geochemical studies of lower crustal xenoliths carried to the surface by post-Grampian volcanism (Halliday et al. 1993). It would also show that exotic microcontinents within the Grampian-Taconic arcs (e.g. Hibbard, Tracy \& Henika, 2003) are more extensive than previously recognized.

\section{Crystalline basement in Ireland}

\section{2.a. Laurentian basement}

The pre-Dalradian Laurentian geology of Ireland is poorly understood as only small inliers of preDalradian rocks are exposed (Fig. 1). Basement inliers of the Rhinns Complex are exposed on the island of Inishtrahull off the north coast of Ireland (Daly, Muir \& Cliff, 1991), and on the islands of Colonsay and Islay in Scotland (Muir, Fitches \& Maltman, 1995). The Rhinns Complex is composed of Palaeoproterozoic (c. $1.78 \mathrm{Ga}$ ) alkaline juvenile crust (Marcantonio et al. 1988; Loewy et al. 2003; Muir, Fitches \& Maltman, 1994; Daly, Muir \& Cliff, 1991; Dickin \& Bowes, 1991) that was metamorphosed shortly after its formation (Roddick \& Max, 1975). The Annagh Gneiss Complex, exposed in a small inlier in $\mathrm{W}$ Ireland, differs from the Rhinns Complex in that its Palaeoproterozoic component is slightly younger and it contains extensive Mesoproterozoic intrusions (c. $1.27 \mathrm{Ga}$ ), termed the Cross Point Gneiss, which variably rework the older Mullet Gneiss protoliths (c. $1.75 \mathrm{Ga}$ ), while others such as the Doolough Gneiss (c. $1.17 \mathrm{Ga}$ ) are juvenile additions (Daly, 1996, 2009). Perhaps most significantly, the Annagh Gneiss Complex was intruded, deformed, metamorphosed and migmatized during the Grenville Orogeny (Daly, 1996; Daly \& Flowerdew, 2005). As Grenville events are not proven to have affected the Rhinns Complex, a major tectonic break, the Grenville front, must be situated between the exposures of the Annagh Gneiss Complex and the Rhinns Complex in Ireland.

As no deep crustal xenoliths have been documented in this part of NW Ireland, extrapolation of the crystalline basement beneath the Slishwood Division and Tyrone Central Inlier is speculative and is dependent on indirect geophysical and geochemical evidence. Deep seismic experiments, summarized by Landes et al. (2005), record variations in Moho depth and anomalously low middle and lower crustal Pwave velocities (Lowe \& Jacob, 1989), which may reflect a change in basement composition. Deep seismic reflection studies have also revealed lithospheric mantle reflectors, which are thought to represent fossil, possibly Palaeoproterozoic, subduction zones (Warner et al. 1996; Snyder, England \& McBride, 1997). These structures led Long \& McConnell (1999) to suggest that Archaean crust may be buried at depth in NW Ireland.

Readman, O'Reilly \& Murphy (1997) note a distinct domain on the Bouguer anomaly map that correlates with the outcrop of the Slishwood Division (Fig. 1), and speculate that this unit is underlain by a single lowdensity body at depth. It may also reflect a different basement character. The Fair Head-Clew Bay Line separates crust of high and low magnetic susceptibility and represents the junction between Laurentia and the Midland Valley Terrane. Crust with a magnetic signature similar to that of the Midland Valley Terrane does occur north of the Fair Head-Clew Bay Line, and spatially overlaps with the gravity anomaly and outcrop area of the Slishwood Division. Both gravity and magnetic data support the interpretation that the Slishwood Division was situated outboard of Laurentia and acted as a rigid indenter during the Grampian Orogeny (Flowerdew et al. 2000). The Tyrone Central Inlier is also situated within the Midland Valley Terrane but has a Laurentian affinity (Chew et al. 2008), probably representing a thin slice of Laurentia thrust onto the Midland Valley Terrane.

In Scotland, granitoid chemistry including $\mathrm{Sr}$ and $\mathrm{Nd}$ isotopes and the age of inherited zircons suggest that the sub-Dalradian basement is similar in character to the Rhinns Complex (Steinhoefel, Hegner \& Oliver, 2008; Pidgeon \& Compston, 1992). Sr and Nd isotopic analyses of the Donegal granites in NW Ireland (Dempsey, Halliday \& Meighan, 1990) are also consistent with the presence of juvenile Palaeoproterozoic basement at depth and also suggest a possible break in the sub-Dalradian basement with more juvenile material SE of the Leannan Fault (Fig. 1). Grampian (c. $470 \mathrm{Ma}$ ) tonalite intrusions cutting the Slishwood Division have $\mathrm{Sr}$ and $\mathrm{Nd}$ isotopic compositions consistent with a derivation from a source similar to the Annagh Gneiss Complex, but the ages of inherited zircons within the tonalites do not (Flowerdew, Daly \& Whitehouse, 2005). This led Flowerdew, Daly \& Whitehouse (2005) to suggest that strong local contamination from the Slishwood Division had masked the geochemical signature of the source, which possibly involved some or all of the Dalradian, Annagh Gneiss Complex and mantle components. The hafnium isotopic data of zircon from a granite sheet from the $\mathrm{Ox}$ Mountains Granodiorite (Chew \& Schaltegger, 2005) 
are also consistent with derivation of this intrusion from a source such as the Annagh Gneiss Complex.

Existing geophysical and geochemical studies, therefore, are consistent with the hidden crystalline basement for the Irish Laurentian margin being analogous to either the Annagh Gneiss Complex or the Rhinns Complex, and that beneath the Slishwood Division is basement, with a character distinct from the rest of the Irish Laurentian margin.

\section{2.b. Basement of the Midland Valley Terrane}

The putative Ordovician arc rocks of the Midland Valley Terrane are mostly concealed by Devonian and younger rocks. Deciphering whether or not the Midland Valley arc had an older continental foundation is difficult. Chew et al. (2008) concluded that the Tyrone Central Inlier, structurally beneath the Ordovician Tyrone Igneous Complex (Cooper, Crowley \& Rushton, 2008), was not equivalent to the basement of the Midland Valley. Nd isotopic data from c. $490 \mathrm{Ma}$ arc rocks in W Ireland have yielded depleted mantle model ages of $1400 \mathrm{Ma}$, suggesting significant assimilation of older crust (Chew, Graham \& Whitehouse, 2007). These authors preferred a model whereby the assimilant took the form of subducted sediment derived from Laurentia rather than any arc basement. Volcanic rocks associated with the Nafooey arc in W Ireland were initially juvenile but become increasingly continental through time (Draut et al. 2004). This trend was interpreted by Draut et al. (2004) to also record the influence of subducted Laurentia-derived sediment as the arc approached and collided with Laurentia. An older continental component to the Midland Valley Terrane has yet to be identified in Ireland.

\section{Sample descriptions}

The samples discussed in this paper come from minor Ordovician intrusions that cut the Slishwood Division and Tyrone Central Inlier in NW Ireland.

Zircons from five intrusions cutting the Slishwood Division were analysed. The Ballygawley Tonalite (MJF 3/95-39A) and Ballygawley granite (MJF 5/9716) were both intruded at c. $470 \mathrm{Ma}$ and contain abundant xenoliths that are lithologically similar to the host Slishwood Division paragneisses (Flowerdew, Daly \& Whitehouse, 2005). The internal structure of the zircons are similar in both of these intrusions (Fig. 2). Cores, sometimes exhibiting a multi-stage growth history, have a varying cathodoluminescence but are normally overgrown by brighter zircon with faint growth zoning (Fig. 2c, e). The overgrowths are thickest at the zircon tips and their contact with the core is often lobate and convoluted, a texture demonstrating that some zircon dissolution of the inherited component has occurred (Williams, 2001). Minor bodies of the same age (c. $470 \mathrm{Ma})$, including a mylonitized granite sheet (MJF 5/97-29) and an undeformed pegmatite (MJF 10/94-2A) that cut the Slishwood Division
(Flowerdew, Daly \& Whitehouse, 2005 and unpub. data), each contain zircons with distinctive internal structures, which differ from those of the tonalites. The pegmatite contains abundant rounded zircon cores with ubiquitous thick non-luminescent overgrowths (Fig. 2b). The granite sheet only rarely yields zircons with inherited cores, and luminescent, growth-zoned acicular zircon grains dominate (Fig. 2d). The final Slishwood Division sample (SG2) comes from a granulite-facies leucosome that pre-dates intrusion of the granite pegmatite suite. Zircon xenocrysts from this sample are considered to be original detrital grains that were scavenged from the metasedimentary wall rock during intrusion. These only rarely have thin overgrowths, which are too thin to be analysed for their Hf isotope composition.

Zircons from a single sample cutting the Tyrone Igneous Complex (TCI-10) come from a c. $470 \mathrm{Ma}$ granite pegmatite (Chew et al. 2008) with similar field relationships and zircon textures (Fig. 2a) to that of the Slishwood Division pegmatite (MJF 10/94-2A). However, thick rims are extremely rare.

\section{Analytical method}

$\mathrm{Lu}-\mathrm{Hf}$ isotope analyses were performed in spring 2005 at the NERC Isotope Geosciences Laboratory, Keyworth, UK, following U-Pb zircon ion-microprobe geochronology at the NORDSIM facility, Swedish Museum of Natural History, Stockholm. In situ Hf isotope analyses were performed using a Merchantek 266nm Nd:YAG laser attached to a VG instruments multi-collector Axiom inductively coupled plasma mass spectrometer. The analytical method is modified after Flowerdew et al. (2006) and is briefly described below. Ablations, which resulted in approximately cylindrical pits with dimensions of $50 \mu \mathrm{m}$ diameter $\times 50 \mu \mathrm{m}$ depth, were targeted over the $\mathrm{U}-\mathrm{Pb}$ ionmicroprobe analysis spot. Where this was not possible, or where magmatic rims overgrowing inherited zircon were obvious, CL images were used to ensure that the Hf analysis was from the same growth zone of zircon on which $\mathrm{U}-\mathrm{Pb}$ dating was performed.

Isobaric interferences of $\mathrm{Yb}$ and $\mathrm{Lu}$ on the 176 peak were corrected for using a dual approach, firstly by doping solution standards to determine ${ }^{176} \mathrm{Yb} /{ }^{173} \mathrm{Yb}$ (Thirlwall \& Walder, 1995), and secondly by determining $\mathrm{Yb}$ mass bias in situ during ablation (Woodhead et al. 2004). In the first approach, a Yb solution was mixed with the JMC 475 Hf solution standard to achieve a range of $\mathrm{Yb} / \mathrm{Hf}$ ratios $(0.02,0.07$ and 0.1$)$ in order to determine an empirical vale for the ${ }^{176} \mathrm{Yb} /{ }^{173} \mathrm{Yb}$ ratio. This value $\left({ }^{176} \mathrm{Yb} /{ }^{173} \mathrm{Yb}=0.79505\right)$ was then used to correct for the interference of ${ }^{176} \mathrm{Yb}$ on ${ }^{176} \mathrm{Hf}$ for the ablations. The $\mathrm{Yb}$ mass bias corrections for $\mathrm{Yb}$ were assumed to be similar to that for the measured ${ }^{179} \mathrm{Hf} /{ }^{177} \mathrm{Hf}$. Although the mass bias behaviour of $\mathrm{Hf}$ and $\mathrm{Yb}$ is subtly different ( $\mathrm{Wu}$ et al. 2006), the assumption is appropriate for grains with low $\mathrm{Yb}$ concentrations. Doped and undoped analyses 

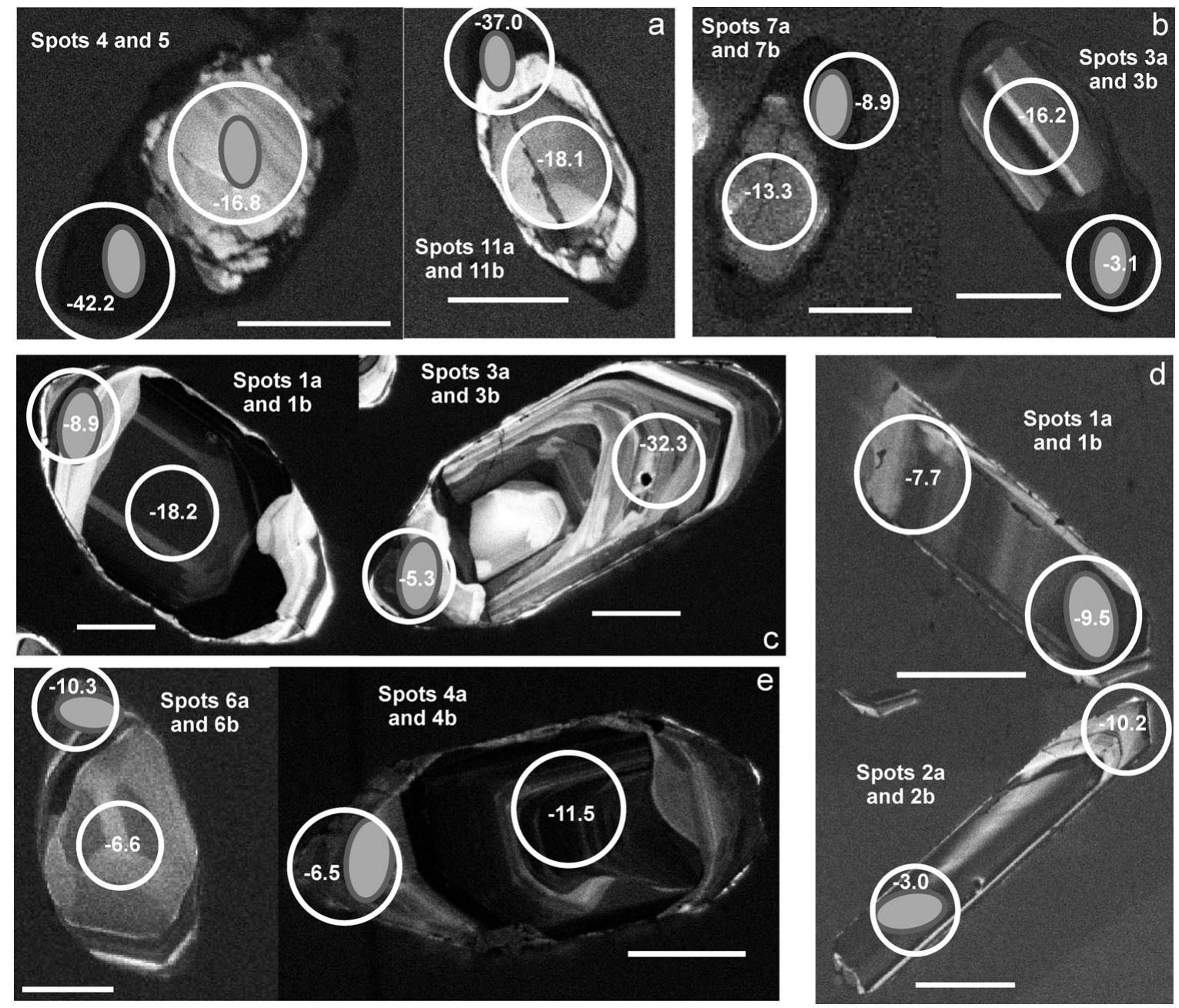

Figure 2. Zircon CL images from granitoids cutting the Slishwood Division and the Tyrone Central Inlier. Representative images for each sample are shown for: TCI-10 in (a); MJF 10/94-2A in (b), MJF 5/97-16 in (c), MJF 5/97-29 in (d) and MJF 3/95-39A in (e). Grey ellipses show location of ion-microprobe spots and white circles the location of $\mathrm{Hf}$ laser ablation spots, together with the $\mathrm{EHf}_{470}$ values for the analysis. Each grain is labelled corresponding to the grain number indicated in Table 1 and the adjacent white scalebar is $50 \mu \mathrm{m}$.

of the JMC 475 standard yielded ${ }^{176} \mathrm{Hf} /{ }^{177} \mathrm{Hf}$ values of $0.282129 \pm 21$ (2 standard deviations, $\mathrm{n}=38$ ) and $0.282130 \pm 19$ ( 2 standard deviations, $\mathrm{n}=32$ ), respectively, and are within the long term laboratory average of $0.282146 \pm 74$ for the Axiom instrument. A ${ }^{176} \mathrm{Lu} /{ }^{175} \mathrm{Lu}$ value of 0.02645 was determined through successive Lu doping of the JMC 475 standard. The second method determined the $\mathrm{Yb}$ mass bias using the interference-free ${ }^{173} \mathrm{Yb} /{ }^{172} \mathrm{Yb}$ ratio averaged over the course of the ablation, and used the $\mathrm{Yb}$ natural abundance ratios of Thirlwall \& Anczkiewicz (2004) in order to correct for the interfering ${ }^{176} \mathrm{Yb}$. Intermittent ablations of the 91500 zircon standard within each of the analytical sessions yielded ${ }^{176} \mathrm{Hf} /{ }^{177} \mathrm{Hf}$ values of $0.282294 \pm 55$ and $0.282297 \pm 96$ (2 standard deviations, $\mathrm{n}=89$ ), in agreement with reported values of $\sim 0.28230$ (Blichert-Toft, 2008; Wiedenbeck et al. 1995). Any Hf isotopic heterogeneity in the 91500 zircon (e.g. Griffin et al. 2006) would overestimate the external reproducibility.

Neither method of reduction is ideal. The second in situ method suffers from a greater uncertainty and reproducibility of the ${ }^{176} \mathrm{Hf} /{ }^{177} \mathrm{Hf}$ ratio. The greater imprecision is caused by the combined effect of lower signal intensities and a less precise determination of the $\mathrm{Yb}$ mass bias compared with the first method. Additionally, several different natural abundance values for $\mathrm{Yb}$ are currently in use. The natural abundance values of Thirlwall \& Anczkiewicz (2004) were adopted, as they fit best the $\mathrm{Yb}$ corrections of zircon standards (e.g. Wu et al. 2006) but they may not necessarily be correct. The first method is considered inaccurate for zircons with moderate and high ${ }^{176} \mathrm{Yb} /{ }^{177} \mathrm{Hf}(\mathrm{Wu}$ et al. 2006). The proposed degree of inaccuracy, which is approximately $20 \mathrm{ppm}$ for zircons with ${ }^{176} \mathrm{Yb} /{ }^{177} \mathrm{Hf}<0.04$, is accommodated by our average $2.0 \mathrm{EHf}$ uncertainty $(2 \sigma)$. In fact, the two methods of $\mathrm{Yb}$-correction yield results that are in broad agreement, with just 6 out of 59 analyses not agreeing within analytical uncertainty. Hf isotopic ratios are quoted using both reduction methods in Table 1, and all figures use the values determined by the first, doping method. Additionally, the external precision of approximately $2.0 \mathrm{EHf}$ units is more than adequate to resolve different 
Table 1. Hf isotopic data

\begin{tabular}{|c|c|c|c|c|c|c|c|c|c|c|c|c|c|c|c|}
\hline \multirow[b]{2}{*}{$\mathrm{ID}^{1}$} & \multirow[b]{2}{*}{ Anal $^{2}$} & \multirow[b]{2}{*}{$\mathrm{Age}^{3}$} & \multirow[b]{2}{*}{${ }^{176} \mathrm{Lu} /{ }^{177} \mathrm{Hf}$} & \multirow[b]{2}{*}{${ }^{176} \mathrm{Yb} /{ }^{177} \mathrm{Hf}$} & \multirow[b]{2}{*}{ Conc $^{4}$} & \multicolumn{5}{|c|}{ Yb correction: doping method ${ }^{5}$} & \multicolumn{5}{|c|}{ Yb correction: in situ method $^{8}$} \\
\hline & & & & & & ${ }^{176} \mathrm{Hf} /{ }^{177} \mathrm{Hf}$ & $\pm 2 \sigma$ & $\varepsilon \mathrm{Hf}_{470}{ }^{6}$ & $\pm 2 \sigma$ & $t_{\mathrm{DM}}{ }^{7}$ & ${ }^{176} \mathrm{Hf} /{ }^{177} \mathrm{Hf}$ & $\pm 2 \sigma$ & $\varepsilon \mathrm{Hf}_{470}{ }^{6}$ & $\pm 2 \sigma$ & $t_{\mathrm{DM}}{ }^{7}$ \\
\hline \multicolumn{16}{|c|}{ MJF 3/95-39A: Ballygawley Tonalite-Ballygawley-Slishwood Division } \\
\hline $6 a$ & rim & 470 & 0.0002 & 0.0073 & 1.9 & 0.282180 & 0.000051 & -10.7 & 1.8 & 1481 & 0.282184 & 0.000055 & -10.5 & 1.9 & 1475 \\
\hline 1a & rim & 470 & 0.0002 & 0.0091 & 2.0 & 0.282224 & 0.000057 & -9.1 & 2.0 & 1422 & 0.282219 & 0.000061 & -9.3 & 2.2 & 1429 \\
\hline A & rim & 470 & 0.0014 & 0.0420 & 2.3 & 0.282254 & 0.000036 & -8.4 & 1.3 & 1424 & 0.282221 & 0.000041 & -9.6 & 1.4 & 1471 \\
\hline B1 & rim & 470 & 0.0002 & 0.0091 & 2.4 & 0.282221 & 0.000031 & -9.3 & 1.1 & 1428 & 0.282201 & 0.000036 & -9.9 & 1.3 & 1454 \\
\hline $2 \mathrm{a}$ & rim & 470 & 0.0002 & 0.0094 & 2.1 & 0.282201 & 0.000053 & -10.0 & 1.9 & 1455 & 0.282192 & 0.000057 & -10.3 & 2.0 & 1467 \\
\hline $4 a$ & rim & 470 & 0.0002 & 0.0098 & 2.6 & 0.282297 & 0.000044 & -6.5 & 1.6 & 1322 & 0.282284 & 0.000049 & -7.0 & 1.7 & 1340 \\
\hline $4 \mathrm{~b}$ & core & - & 0.0009 & 0.0393 & 1.4 & 0.282162 & 0.000050 & -11.5 & 1.8 & 1534 & 0.282198 & 0.000054 & -10.3 & 1.9 & 1484 \\
\hline $6 \mathrm{~b}^{*}$ & core & - & 0.0010 & 0.0417 & 1.0 & 0.282291 & 0.000067 & -7.0 & 2.4 & 1357 & 0.282144 & 0.000071 & -12.2 & 2.5 & 1562 \\
\hline $1 \mathrm{~b}$ & core & - & 0.0024 & 0.0908 & 0.9 & 0.281890 & 0.000065 & -21.6 & 2.3 & 1988 & 0.281869 & 0.000070 & -22.4 & 2.5 & 2018 \\
\hline A2 & core & - & 0.0017 & 0.0699 & 0.9 & 0.282171 & 0.000064 & -11.5 & 2.3 & 1552 & 0.282120 & 0.000069 & -13.3 & 2.4 & 1625 \\
\hline B2 & core & - & 0.0009 & 0.0389 & 1.5 & 0.282047 & 0.000048 & -15.6 & 1.7 & 1694 & 0.282053 & 0.000052 & -15.4 & 1.8 & 1686 \\
\hline $2 b$ & core & - & 0.0007 & 0.0294 & 1.2 & 0.281910 & 0.000063 & -20.4 & 2.2 & 1874 & 0.281825 & 0.000068 & -23.4 & 2.4 & 1990 \\
\hline \multicolumn{16}{|c|}{ MJF 5/97-16: Ballygawley Granite-Ballygawley-Slishwood Division } \\
\hline 1a & rim & 470 & 0.0005 & 0.0162 & 1.7 & 0.282232 & 0.000062 & -8.9 & 2.2 & 1422 & 0.282203 & 0.000066 & -10.0 & 2.3 & 1463 \\
\hline $2 a$ & rim & 470 & 0.0007 & 0.0218 & 2.0 & 0.282229 & 0.000058 & -9.1 & 2.1 & 1432 & 0.282299 & 0.000062 & -6.6 & 2.2 & 1335 \\
\hline $4 a$ & rim & 470 & 0.0004 & 0.0148 & 1.9 & 0.282281 & 0.000073 & -7.2 & 2.6 & 1350 & 0.282266 & 0.000077 & -7.7 & 2.7 & 1372 \\
\hline $3 a$ & rim & 470 & 0.0004 & 0.0136 & 1.3 & 0.282334 & 0.000117 & -5.3 & 4.2 & 1277 & 0.282268 & 0.000121 & -7.6 & 4.3 & 1368 \\
\hline $5 a$ & rim & 470 & 0.0003 & 0.0119 & 1.8 & 0.282233 & 0.000043 & -8.8 & 1.5 & 1414 & 0.282273 & 0.000047 & -7.4 & 1.7 & 1359 \\
\hline $6 a$ & rim & 470 & 0.0006 & 0.0220 & 1.5 & 0.282243 & 0.000066 & -8.6 & 2.3 & 1410 & 0.282237 & 0.000069 & -8.8 & 2.5 & 1418 \\
\hline $\mathrm{A} 1$ & rim & 470 & 0.0007 & 0.0287 & 1.6 & 0.282242 & 0.000087 & -8.6 & 3.1 & 1414 & 0.282251 & 0.000091 & -8.3 & 3.2 & 1401 \\
\hline $1 \mathrm{~b}$ & core & - & 0.0008 & 0.0322 & 0.9 & 0.281972 & 0.000067 & -18.2 & 2.4 & 1792 & 0.281922 & 0.000071 & -20.0 & 2.5 & 1862 \\
\hline $2 b$ & core & 1016 & 0.0008 & 0.0354 & 1.1 & 0.282066 & 0.000043 & -14.9 & 1.5 & 1662 & 0.282078 & 0.000047 & -14.5 & 1.7 & 1647 \\
\hline $4 b$ & core & - & 0.0011 & 0.0426 & 0.8 & 0.282175 & 0.000081 & -11.1 & 2.9 & 1522 & 0.282316 & 0.000085 & -6.1 & 3.0 & 1326 \\
\hline $3 b$ & core & - & 0.0011 & 0.0476 & 0.9 & 0.281578 & 0.000075 & -32.3 & 2.7 & 2350 & 0.281593 & 0.000079 & -31.7 & 2.8 & 2329 \\
\hline $5 b$ & core & - & 0.0011 & 0.0437 & 0.9 & 0.281995 & 0.000069 & -17.5 & 2.5 & 1773 & 0.282027 & 0.000073 & -16.4 & 2.6 & 1728 \\
\hline $6 \mathrm{~b}$ & core & - & 0.0011 & 0.0460 & 0.8 & 0.281707 & 0.000075 & -27.7 & 2.7 & 2177 & 0.281857 & 0.000079 & -22.4 & 2.8 & 1969 \\
\hline $\mathrm{A} 2$ & core & - & 0.0008 & 0.0294 & 0.9 & 0.281906 & 0.000067 & -20.6 & 2.4 & 1881 & 0.281962 & 0.000071 & -18.6 & 2.5 & 1804 \\
\hline \multicolumn{16}{|c|}{ MJF 10/94-2A: Granite pegmatite sheet-Kilerry Mountain-Slishwood Division } \\
\hline $7 a^{*}$ & rim & 470 & 0.0005 & 0.0162 & 2.8 & 0.282232 & 0.000062 & -8.9 & 2.2 & 1422 & 0.282403 & 0.000064 & -2.9 & 2.3 & 1186 \\
\hline $6 a$ & rim & 470 & 0.0028 & 0.1010 & 2.5 & 0.282319 & 0.000066 & -6.6 & 2.3 & 1383 & 0.282219 & 0.000068 & -10.1 & 2.4 & 1529 \\
\hline $3 a^{*}$ & rim & 470 & 0.0031 & 0.1279 & 3.2 & 0.282419 & 0.000040 & -3.1 & 1.4 & 1250 & 0.282328 & 0.000042 & -6.3 & 1.5 & 1384 \\
\hline $4 a^{*}$ & rim & 470 & 0.0035 & 0.1300 & 2.5 & 0.282276 & 0.000062 & -8.3 & 2.2 & 1474 & 0.282141 & 0.000064 & -13.1 & 2.3 & 1676 \\
\hline $8 \mathrm{a}$ & rim & 470 & 0.0007 & 0.0283 & 2.3 & 0.282346 & 0.000072 & -5.0 & 2.5 & 1273 & 0.282247 & 0.000074 & -8.5 & 2.6 & 1409 \\
\hline $7 \mathrm{~b}$ & core & - & 0.0012 & 0.0496 & 1.8 & 0.282116 & 0.000054 & -13.3 & 1.9 & 1610 & 0.282019 & 0.000056 & -16.7 & 2.0 & 1745 \\
\hline $6 \mathrm{~b}$ & core & - & 0.0015 & 0.0584 & 1.8 & 0.281855 & 0.000059 & -22.6 & 2.1 & 1987 & 0.281769 & 0.000061 & -25.6 & 2.1 & 2107 \\
\hline $3 b$ & core & - & 0.0014 & 0.0534 & 1.2 & 0.282034 & 0.000063 & -16.2 & 2.2 & 1733 & 0.282023 & 0.000065 & -16.6 & 2.3 & 1748 \\
\hline $8 \mathrm{~b}$ & core & - & 0.0016 & 0.0558 & 1.3 & 0.282115 & 0.000069 & -13.4 & 2.5 & 1630 & 0.281998 & 0.000071 & -17.6 & 2.5 & 1795 \\
\hline 1 & core & 929 & 0.0008 & 0.0280 & 0.7 & 0.282078 & 0.000108 & -14.5 & 3.8 & 1644 & 0.282132 & 0.000110 & -12.5 & 3.9 & 1569 \\
\hline 2 & core & 994 & 0.0007 & 0.0271 & 0.7 & 0.282192 & 0.000092 & -10.4 & 3.3 & 1485 & 0.282096 & 0.000094 & -13.8 & 3.3 & 1617 \\
\hline
\end{tabular}




\begin{tabular}{|c|c|c|c|c|c|c|c|c|c|c|c|c|c|c|c|}
\hline \multicolumn{16}{|c|}{ MJF 5/97-29: Granite sheet-Lough Keola-Slishwood Division } \\
\hline 1a & rim & 470 & 0.0008 & 0.0375 & 1.9 & 0.282220 & 0.000054 & -9.5 & 1.9 & 1451 & 0.282208 & 0.000056 & -9.9 & 2.0 & 1467 \\
\hline $1 \mathrm{~b}$ & rim & 470 & 0.0011 & 0.0586 & 2.1 & 0.282271 & 0.000038 & -7.7 & 1.3 & 1391 & 0.282364 & 0.000040 & -4.5 & 1.4 & 1260 \\
\hline $2 \mathrm{a}$ & rim & 470 & 0.0005 & 0.0306 & 2.7 & 0.282400 & 0.000044 & -3.0 & 1.6 & 1190 & 0.282385 & 0.000047 & -3.5 & 1.6 & 1211 \\
\hline $2 \mathrm{~b}$ & rim & 470 & 0.0006 & 0.0265 & 2.4 & 0.282198 & 0.000070 & -10.2 & 2.5 & 1472 & 0.282258 & 0.000072 & -8.0 & 2.5 & 1388 \\
\hline 4 & rim & 470 & 0.0004 & 0.0257 & 2.3 & 0.282425 & 0.000052 & -2.1 & 1.8 & 1153 & 0.282417 & 0.000054 & -2.3 & 1.9 & 1164 \\
\hline 5 & rim & 470 & 0.0002 & 0.0080 & 1.4 & 0.282181 & 0.000054 & -10.6 & 1.9 & 1478 & 0.282179 & 0.000056 & -10.7 & 2.0 & 1481 \\
\hline $6^{*}$ & core & 1629 & 0.0031 & 0.1185 & 1.2 & 0.281797 & 0.000096 & -25.1 & 3.4 & 2160 & 0.282181 & 0.000098 & -11.5 & 3.5 & 1597 \\
\hline \multicolumn{16}{|c|}{ SG2: Leucosome-Slishwood Gap-Slishwood Division } \\
\hline $1^{*}$ & core & 968 & 0.0008 & 0.0257 & 1.1 & 0.282031 & 0.000081 & -16.1 & 2.9 & 1709 & 0.282207 & 0.000084 & -9.9 & 3.0 & 1465 \\
\hline 2 & core & 955 & 0.0008 & 0.0247 & 1.7 & 0.282178 & 0.000071 & -11.0 & 2.5 & 1509 & 0.282251 & 0.000073 & -8.4 & 2.6 & 1407 \\
\hline 3 & core & 1180 & 0.0020 & 0.0919 & 1.9 & 0.282231 & 0.000083 & -9.5 & 2.9 & 1483 & 0.282330 & 0.000085 & -5.9 & 3.0 & 1340 \\
\hline \multicolumn{16}{|c|}{ TCI-10: Leucosome-Hill-Tyrone Central Inlier } \\
\hline 4 & rim & 470 & 0.0105 & 0.3451 & 2.1 & 0.281381 & 0.000082 & -42.2 & 2.9 & 3479 & 0.281461 & 0.000083 & -39.4 & 3.0 & 3335 \\
\hline $10 \mathrm{a}$ & rim & 470 & 0.0048 & 0.1476 & 0.6 & 0.281703 & 0.000136 & -29.0 & 4.8 & 2415 & 0.281943 & 0.000138 & -20.5 & 4.9 & 2048 \\
\hline $11 \mathrm{a}$ & rim & 470 & 0.0072 & 0.2559 & 2.2 & 0.281527 & 0.000073 & -36.0 & 2.6 & 2885 & 0.281499 & 0.000075 & -37.0 & 2.6 & 2930 \\
\hline 5 & core & 1192 & 0.0011 & 0.0480 & 1.2 & 0.282015 & 0.000058 & -16.8 & 2.1 & 1748 & 0.281956 & 0.000060 & -18.9 & 2.1 & 1830 \\
\hline 1 & core & 2748 & 0.0016 & 0.0750 & 1.8 & 0.281170 & 0.000069 & -46.9 & 2.4 & 2951 & 0.281161 & 0.000070 & -47.2 & 2.5 & 2963 \\
\hline 2 & core & $2625^{\S}$ & 0.0016 & 0.0730 & 2.4 & 0.281173 & 0.000038 & -46.7 & 1.3 & 2943 & 0.281220 & 0.000040 & -45.1 & 1.4 & 2879 \\
\hline $10 \mathrm{~b}$ & core & $2366^{\S}$ & 0.0012 & 0.0430 & 1.8 & 0.281137 & 0.000057 & -47.9 & 2.0 & 2959 & 0.281227 & 0.000058 & -44.7 & 2.1 & 2837 \\
\hline 6 & core & 1051 & 0.0015 & 0.0655 & 2.2 & 0.282109 & 0.000076 & -13.6 & 2.7 & 1631 & 0.282171 & 0.000077 & -11.4 & 2.7 & 1543 \\
\hline 7 & core & $1141^{\S}$ & 0.0019 & 0.0831 & 1.3 & 0.282174 & 0.000078 & -11.4 & 2.7 & 1556 & 0.282243 & 0.000079 & -8.9 & 2.8 & 1457 \\
\hline 8 & core & 1024 & 0.0007 & 0.0279 & 3.2 & 0.282153 & 0.000074 & -11.8 & 2.6 & 1539 & 0.282116 & 0.000076 & -13.1 & 2.7 & 1590 \\
\hline 9 & core & 1816 & 0.0016 & 0.0656 & 1.2 & 0.281949 & 0.000047 & -19.3 & 1.7 & 1863 & 0.281967 & 0.000048 & -18.6 & 1.7 & 1837 \\
\hline $11 \mathrm{~b}$ & core & - & 0.0010 & 0.0403 & 2.0 & 0.281977 & 0.000076 & -18.1 & 2.7 & 1796 & 0.282078 & 0.000078 & -14.5 & 2.8 & 1654 \\
\hline
\end{tabular}

${ }^{1}$ Grain and analysis identification; asterisk indicates analyses where the two different reduction methods do not agree within analytical uncertainty. ${ }^{2}$ Portion of zircon analysed, inferred from CL images of grains. ${ }^{3} \mathrm{U}-\mathrm{Pb}$ age of rims averages $470 \mathrm{Ma}$ and this age is taken for all rim analyses; $\S$ indicates ${ }^{207} \mathrm{~Pb} /{ }^{206} \mathrm{~Pb}$ age when anchored through $470 \mathrm{Ma}$. ${ }^{4} \mathrm{Total} \mathrm{Hf}$ volts measured during analysis as an indication of relative $\mathrm{Hf}$ concentration. ${ }^{5}$ Values obtained using the doping method for removal of interfering ${ }^{176} \mathrm{Lu}$ and ${ }^{176} \mathrm{Yb}$ isotopes. ${ }^{6,7} \mathrm{EHf}$ at $470 \mathrm{Ma}$ and depleted mantle model ages calculated using a Lu decay

constant of $1.865 \times 10^{-11}$ (Amelin, 2005; Scherer, Münker \& Mezger, 2001) and modern-day chondrite values of ${ }^{176} \mathrm{Hf} /{ }^{177} \mathrm{Hf}$ and ${ }^{176} \mathrm{Lu} /{ }^{177} \mathrm{Hf}$ of $0.282772 \mathrm{and} 0.0332$, respectively $(\mathrm{Blichert}-\mathrm{Toft} \&$ Albarède, 1997). Depleted mantle model ages were calculated using the measured ${ }^{176} \mathrm{Lu} /{ }^{177} \mathrm{Hf}$ of the zircon and present day ${ }^{176} \mathrm{Hf} /{ }^{177} \mathrm{Hf}$ and ${ }^{176} \mathrm{Lu} /{ }^{177} \mathrm{Hf}$ values of 0.28325 and 0.0384 , respectively (Griffin $e t$ al. 2004 ). ${ }^{8}$ Values obtained using the in situ method for the removal of interfering ${ }^{176} \mathrm{Lu}$ and ${ }^{176} \mathrm{Yb}$. 


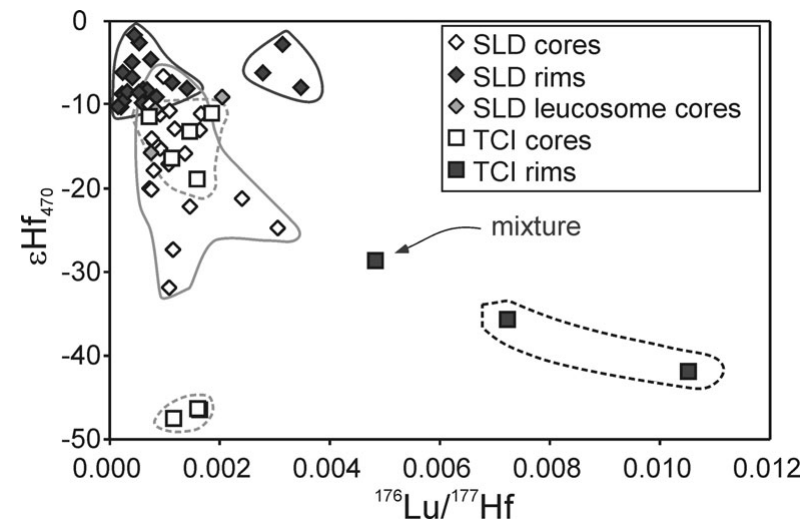

Figure 3. ${ }^{176} \mathrm{Lu} /{ }^{177} \mathrm{Hf}$ against $\varepsilon \mathrm{Hf}$ for the analysed zircon. Solid black line defines the field for the Slishwood Division rims and solid grey line defines the field for the Slishwood Division cores. Dashed black line defines the field for the Tyrone Central Inlier rims and the dashed grey lines the field for the Tyrone Central Inlier cores. Abbreviations: SLD - Slishwood Division, TCI Tyrone Central Inlier.

basement provinces or source regions, given the wide range in initial $\mathrm{Hf}$ isotopic compositions determined in this study.

\section{Results}

Results are given in Table 1 and are presented graphically in Figures 3 and 4.

The zircon rims from the Slishwood Division intrusions are generally distinct from their cores (Fig. 3; Table 1), several of which are known to be inherited, based on their $\mathrm{U}-\mathrm{Pb}$ ages (Table 1). Rim compositions exhibit two clusters, one at about ${ }^{176} \mathrm{Lu} /{ }^{177} \mathrm{Hf}=0.0005$ and $\varepsilon \mathrm{Hf}_{470}=-9$ and the other at ${ }^{176} \mathrm{Lu} /{ }^{177} \mathrm{Hf}=0.003$ and $\varepsilon_{\mathrm{Hf}} \mathrm{H}_{400}=-6$. The Slishwood Division cores have ${ }^{176} \mathrm{Lu} /{ }^{177} \mathrm{Hf}$ values ranging between 0.0005 and 0.003 and $\mathrm{EHf}_{470}$ between -7 and -32 . While the fields for

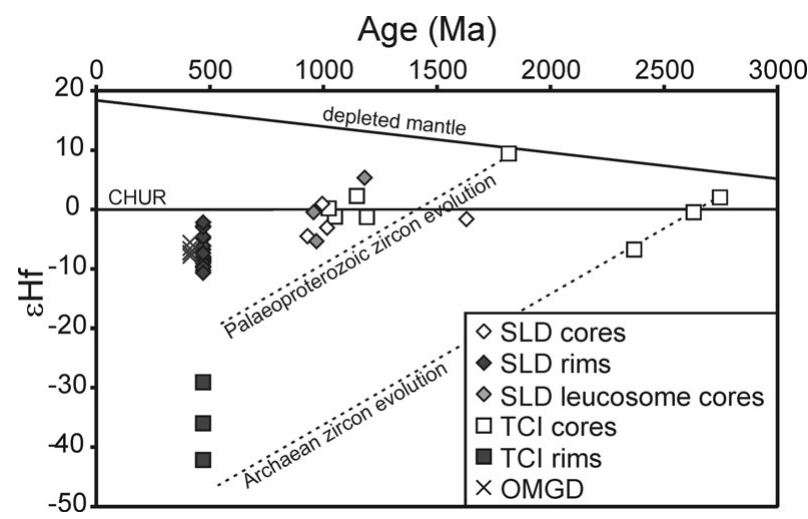

Figure 4. Age against $\varepsilon \mathrm{Hf}$ evolution plot for the c. $470 \mathrm{Ma}$ zircon rims and zircon cores of known age. Dashed lines show the $\varepsilon H f$ evolution for two grains from the Tyrone Central Inlier with ${ }^{176} \mathrm{Lu} /{ }^{177} \mathrm{Hf}$ of 0.0016 (the average value for the inherited cores) and act as a guide for the $\varepsilon \mathrm{Hf}$ evolution of the other core analyses. Abbreviations: SLD - Slishwood Division, TCI - Tyrone Central Inlier, OMGD - magmatic zircon from the $412 \mathrm{Ma}$ Ox Mountains Granodiorite (Chew \& Schaltegger, 2005). the cores and rims overlap, many of the cores have higher ${ }^{176} \mathrm{Lu} /{ }^{177} \mathrm{Hf}$ ratios and most have significantly lower $\varepsilon \mathrm{Hf}_{470}$ than the zircon overgrowths that crystallized during intrusion.

Zircon rims from the Tyrone Central Inlier are also distinct from the cores (Fig. 3). The cores are interpreted as inherited on the basis that they yield older $\mathrm{U}-\mathrm{Pb}$ ages than the rims (Table 1). Rims (excluding analysis 10a which is an inadvertent mixture between core and rim) have extremely high ${ }^{176} \mathrm{Lu} /{ }^{177} \mathrm{Hf}>0.007$ coupled with extremely low $\varepsilon \mathrm{Hf}_{470}$ at approximately -40 . Although analysis $10 \mathrm{a}$ is a mixture, its intermediate ${ }^{176} \mathrm{Lu} /{ }^{177} \mathrm{Hf}$ ratio (Table 1) is consistent with the rim for this grain having low $\mathrm{eHf}_{470}$ and high ${ }^{176} \mathrm{Lu} /{ }^{177} \mathrm{Hf}$ values similar to the other two rim analyses. Inherited zircons from the Tyrone Central Inlier form two distinct clusters. One has ${ }^{176} \mathrm{Lu} /{ }^{177} \mathrm{Hf}$ ratios of 0.0015 and $\varepsilon \mathrm{Hf}_{470}$ values ranging between -11 and -19 , the other also has ${ }^{176} \mathrm{Lu} /{ }^{177} \mathrm{Hf}$ ratios of 0.0015 but with $\varepsilon \mathrm{Hf}_{470}$ values of -47 (Fig. 3).

The ages of many zircon cores in the Slishwood Division rocks are not known, but for those cores for which there is age information, the $\mathrm{U}-\mathrm{Pb}$ age versus \&Hf plot (Fig. 4; Table 1) is most revealing. The Slishwood Division cores have \&Hf values close to zero and formed from a Palaeoproterozoic to early Mesoproterozoic source. The Tyrone Central Inlier also contains cores that cluster close to those from the Slishwood Division and indicate a similar origin. In addition, however, the Tyrone Central Inlier contains Neoarchaean cores derived from a Mesoarchaean source.

\section{Interpretation and discussion}

\section{6.a. Identifying sources of granitoids through hafnium isotopes}

Any rock will have a $\mathrm{Hf}$ isotope composition that evolves through time at a rate dependent on its whole rock $\mathrm{Lu} / \mathrm{Hf}$ ratio. The rock, of course, comprises different minerals themselves with varying concentrations of lutetium and hafnium and varying $\mathrm{Hf}$ isotope compositions. The relative behaviour of these compositionally different minerals during melting will control the isotope composition of the resultant melt. Zircon is particularly important on two counts. Not only is it essentially lutetium-free and thus retains a nearly constant hafnium isotopic composition through time, effectively recording the composition of fluid from which it grew, it is also extremely Hf-rich and typically accounts for most of the hafnium in silicic rocks (e.g. Hoskin et al. 2000). Therefore, if zircon in a source rock dissolves during partial melting, the resulting hafnium isotopic composition of the melt will be less radiogenic than if zircon did not dissolve or was not present initially (Flowerdew et al. 2006; Wu et al. 2007). In the latter case, the melt composition will be influenced by other pre-existing or co-precipitating phases (Zheng et al. 2005) and will usually inherit a 
signature close to that of the whole rock (e.g. Zeh et al. 2007). Identifying whether or not zircon has dissolved is therefore paramount for any interpretation regarding the melted source. One way of demonstrating that zircon dissolution into the melt has occurred is by examining the texture of overgrown inherited zircon cores (Williams, 2001; Wu et al. 2007). The absence of textural evidence for zircon dissolution of the inherited component does not of course preclude zircon dissolution having taken place.

\section{6.b. Source of Slishwood Division granitoid intrusions and leucosome}

\section{6.b.1. Zircon core compositions}

The inherited zircon components from the Slishwood Division intrusions have an average $\varepsilon \mathrm{Hf}$ value of $-16.3 \pm 2.4$ and $t_{\text {DM }}$ ages of $c .1740$ Ma ('c' on Fig. 5). While the ages for the majority of cores are not known, seven of the Hf analyses come from cores that have a corresponding $\mathrm{U}-\mathrm{Pb}$ ion-microprobe age. These grains together with the inherited grains within the Giant's Rock Tonalite (for which Hf data is not available) have age populations corresponding with the age populations for detrital grains from the Slishwood

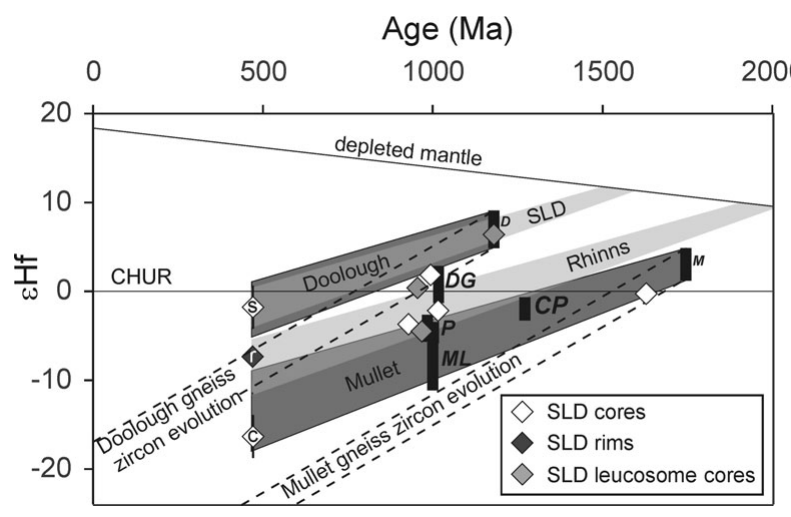

Figure 5. Age against $\varepsilon \mathrm{Hf}$ evolution plot showing the evolution fields for possible sources for the Slishwood Division-hosted intrusions. Labelled diamonds show $\mathrm{EHf}_{470}$ for the average rim composition, ' $r$ '; the average core composition, 'c' (including all $\mathrm{Hf}$ analyses for which the inherited core age is not known); and the zircon composition predicted if Slishwood Division were to melt without significant zircon dissolution, 's'. Black bars represent the $\varepsilon H f$ ranges for the Annagh Gneiss protoliths (adapted from Daly, 2009) where: $M$ - Mullet gneiss (with one analysis excluded), $C P$ - Cross Point gneiss, $D$ - Doolough gneiss, $D G$ - Doolough Granite, $P$ - pegmatites and $M L$ - migmatitic leucosome in Mullet gneiss. Dashed lines show the evolution of zircon with ${ }^{176} \mathrm{Lu} /{ }^{177} \mathrm{Hf}=0.0016$ for the Mullet and Doolough gneisses. Whole-rock evolution trends (dark bands: Mullet and Doolough gneisses; light bands: Slishwood Division SLD and Rhinns Complex - Rhinns) were calculated using an average continental crust ${ }^{176} \mathrm{Lu} /{ }^{177} \mathrm{Hf}$ ratio of $0.015 \pm 0.002$, appropriate considering the strong coupling of the $\mathrm{Sm}-\mathrm{Nd}$ and Lu-Hf systems (Vervoort \& Patchett, 1996) and typical continental crust $\mathrm{Sm} / \mathrm{Nd}$ ratios for the Annagh Gneiss Complex (Menuge \& Daly, 1990) and Rhinns Complex (Marcantonio et al. 1988; Daly, Muir \& Cliff, 1991; Dickin \& Bowes, 1991).
Division (Flowerdew, Daly \& Whitehouse, 2005; Daly et al. 2008). The similarity of their ages, together with the similarity between the collective average c. $1740 \mathrm{Ma} \mathrm{Lu}-\mathrm{Hf}$ model age for the inherited grains with $\mathrm{Sm}-\mathrm{Nd}$ model ages for the Slishwood Division (c. 1560 Ma: Sanders, Daly \& Davies, 1987; Flowerdew \& Daly, 2005), may simply indicate that the cores were incorporated during intrusion rather than being derived from the magmatic source. If this is the case, it could be argued, based on the similarity of age and $\mathrm{Hf}$ isotope composition between the complex and the inherited component, that the Slishwood Division had a sedimentary provenance at least in part from the Annagh Gneiss Complex (Fig. 5). The small number of core analyses with a corresponding age analysis precludes further discussion.

\section{6.b.2. Zircon rim compositions}

Zircon overgrowths in the Slishwood Division intrusions all have similar Hf isotopic compositions. Zircon that grew from the melt was more juvenile (average $\varepsilon H f$ values of $-7.7 \pm 1.1$ and $\mathrm{t}_{\mathrm{DM}}$ ages of $c .1380 \mathrm{Ma}$; Fig. 5) than the inherited component.

Despite textural evidence for some dissolution of the zircon cores, the Hf isotopic composition of the melt was not dominated by this dissolved inherited zircon. This is consistent with the lower $\mathrm{Lu} / \mathrm{Hf}$ of the rims compared with the cores (Fig. 3). The zircon rim composition suggests that it is also unlikely that the granitoid melts were wholly derived by bulk melting of the Slishwood Division paragneisses. Whole rock $\varepsilon_{4 f_{470}}$ values for the Slishwood Division (Fig. 5, calculated assuming coherence between the wholerock $\mathrm{Lu}-\mathrm{Hf}$ and $\mathrm{Sm}-\mathrm{Nd}$ isotopic systems) are too high (less negative) for this to be possible. It is possible, however, that the rim Hf composition (' $r$ ' on Fig. 5) originated from an evolved Slishwood Division at $470 \mathrm{Ma}$ ('s' on Fig. 5) mixed with a component from the inherited zircon ('c' on Fig. 5). This is compatible with the similarity in ages between the inherited grains and detrital grains from the Slishwood Division (see Section 6.b.1). The pegmatite and foliated granite sheet samples, however, do not share the zircon texture of the tonalites. In these cases, the influence of the inherited component on the Hf isotope composition of the melt may be minimal. The similar Hf isotopic character of the zircon rims in all of the intrusions, irrespective of their texture, might indicate that the melts all had a common source other than the Slishwood Division.

$\mathrm{Hf}$ isotope compositions of zircon from the various protoliths forming the Annagh Gneiss Complex are reported by Daly (2009) and are plotted on Figure 5 . Two main Hf isotopic reservoirs exist for the complex: Mullet gneiss and Doolough gneiss. The Doolough Granite is a late Mesoproterozoic intrusion that cuts both Mullet and Doolough gneisses, has a Hf signature in between the two reservoirs and is interpreted to be a mixture of the two reservoirs, while the Cross Point gneiss, pegmatites and leucosome rework the Mullet 
gneiss reservoir in the Mesoproterozoic and early Neoproterozoic, consistent with field, geochemical and other isotopic evidence (Daly, 1996, 2009).

The Mullet gneiss whole-rock reservoir has $\mathrm{EHf}_{470}$ values that range between -9 and -16 . These values overlap with those obtained from inherited core compositions from the Slishwood Division intrusions ('c' on Fig. 5) but are less radiogenic than the rim compositions (' $r$ ' on Fig. 5). The Doolough gneiss reservoir with $\varepsilon \mathrm{Hf}_{470}$ values of +1 to -5 is more radiogenic than both the core and rim compositions from the Slishwood Division intrusions. This means that if zircon dissolution at the source is minimal, then a mixture of the Mullet and Doolough gneiss reservoirs is required to produce the zircon rim composition of the Slishwood Division intrusions. This is not unreasonable, given that the Doolough Granite evidently formed from such a mixture in the late Mesoproterozoic. Alternatively, if zircon dissolution at the source was significant, then only the Doolough gneiss reservoir can produce the compositions recorded in the zircon rims from the Slishwood Division intrusions (Fig. 5).

The Hf isotopic evolution of the Rhinns Complex cannot be assessed accurately since no $\mathrm{Lu}-\mathrm{Hf}$ whole rock data are available. However, if the $\mathrm{Sm}-\mathrm{Nd}$ data from the Rhinns Complex (Marcantonio et al. 1988; Daly, Muir \& Cliff, 1991; Dickin \& Bowes, 1991) are used as a guide for the calculation of the whole rock $\mathrm{Hf}$ isotopic evolution (Fig. 5), a melt derived from the Rhinns Complex would have $\varepsilon \mathrm{Hf}_{470}$ values between -12 and -6 . These values are indistinguishable from the average of the zircon overgrowths in the Slishwood Division (' $r$ ' on Fig. 5). If zircon was dissolved at the source and influenced the melt composition such that it deviated significantly from the whole rock evolution trend, the Rhinns Complex could not be the source, as in this instance the melt would have a Hf composition that is less radiogenic than that recorded in the zircon overgrowths.

$\mathrm{U}-\mathrm{Pb}$ detrital zircon geochronology from the Dalradian Supergroup identifies a broad change in provenance during the development of the Dalradian basin (Cawood et al. 2003; Banks et al. 2007). This is most clearly expressed by the appearance and increasing importance of Archaean detritus stratigraphically upwards. Whole rock $\mathrm{Sm}-\mathrm{Nd}$ data for the metasediments tracks the detrital zircon picture with depleted mantle model ages increasing from an average of $c .1 .77 \mathrm{Ga}$ to $c .2 .06 \mathrm{Ga}$ up-stratigraphy (Menuge \& Daly, 1990; Daly \& Menuge, 1989). LuHf data are not available for the Dalradian or its detrital zircons, so assuming a ${ }^{176} \mathrm{Lu} /{ }^{177} \mathrm{Hf}$ ratio of $0.015 \pm 0.002$ for the metasediments, the Dalradian could potentially yield a granitoid melt with $\varepsilon \mathrm{Hf}_{470}$ ranging between approximately -3 and -14 . The rim composition for the Slishwood Division intrusions could, therefore, be generated from lower to middle Dalradian metasediments. It should be noted, however, that the argument becomes somewhat circular, as lower portions of the Dalradian Supergroup are thought to have been derived from the Annagh Gneiss and Rhinns complexes (Menuge \& Daly, 1990) and so would inherit their geochemical signatures from the eroded basement units. This is also indicated from the inherited zircon component (see Section 6.b.1). If the Dalradian was a source, the resultant melt apparently did not carry with it zircon as an inherited component, as the ages of the inherited grains in the Slishwood Division intrusions do not match well the detrital patterns obtained from the lower Dalradian.

\section{6.c. Source of melts cutting the Tyrone Central Inlier}

The two reliable analyses of overgrowths from the pegmatite cutting the Tyrone Central Inlier have average $\varepsilon \mathrm{Hf}_{470}$ values of $-39.1 \pm 6.2$. The cores have average $\varepsilon \mathrm{Hf}_{470}$ values of -26 ('c' on Fig. 6) but form two distinct populations, with six of the nine grains giving $-16 \pm 3.5$ ('i' on Fig. 6) and the remaining three grains $-47.1 \pm 1$ ('ii' on Fig. 6). The age of the inherited grains broadly matches those obtained from the metasedimentary host (Fig. 7), implying it is a source for the intrusion. The Hf isotopic composition of the zircon overgrowths suggests otherwise. The $\mathrm{Nd}$ depleted mantle model ages of the metasediments are approximately $2100 \mathrm{Ma}$ (Chew et al. 2008) and thus considerably younger than the Archaean depleted mantle Hf model ages for the overgrowths (Fig. 6). For the Tyrone Central Inlier to be a source, not only must zircons have controlled the hafnium isotope signature of the melt but the contributing zircons were selected by age. Only the Archaean zircons could have dissolved, contributing their hafnium, while all younger zircons must have remained intact. While it is not inconceivable that older grains could be preferentially dissolved in view of their longer opportunity to increase their surface area as cracks and pits in the grain, it is more likely that zircons with high $U$ content would achieve this, since radiation damage would be expected to facilitate dissolution. However, in all likelihood the Tyrone Central Inlier was not the source for this melt and by the same arguments neither was the Dalradian Supergroup. Like the Slishwood Division intrusions, it is envisaged that most of the inherited component was picked up during migration and intrusion and was not derived from the melted source region. The source must be entirely Archaean or remelted Archaean crust, or sediment derived from such crust with no significant juvenile component (Fig. 6). Archaean rocks are not known from Ireland but crop out extensively in Scotland in the Lewisian Complex (Fig. 1).The $\mathrm{Sm} / \mathrm{Nd}$ ratios for the Lewisian Complex are generally lower than average continental crust values (Whitehouse, 1989), so assuming coupling of the $\mathrm{Sm}-\mathrm{Nd}$ and $\mathrm{Lu}-\mathrm{Hf}$ systems and a ${ }^{176} \mathrm{Lu} /{ }^{177} \mathrm{Hf}$ of $0.011 \pm 0.002$, Lewisian rocks would evolve to yield $\varepsilon \mathrm{Hf}_{470}$ values of between -26.0 to -34.3 . The evolved Lewisian Complex does not entirely overlap with the overgrowths, as both rim analyses are more negative than the evolved field 


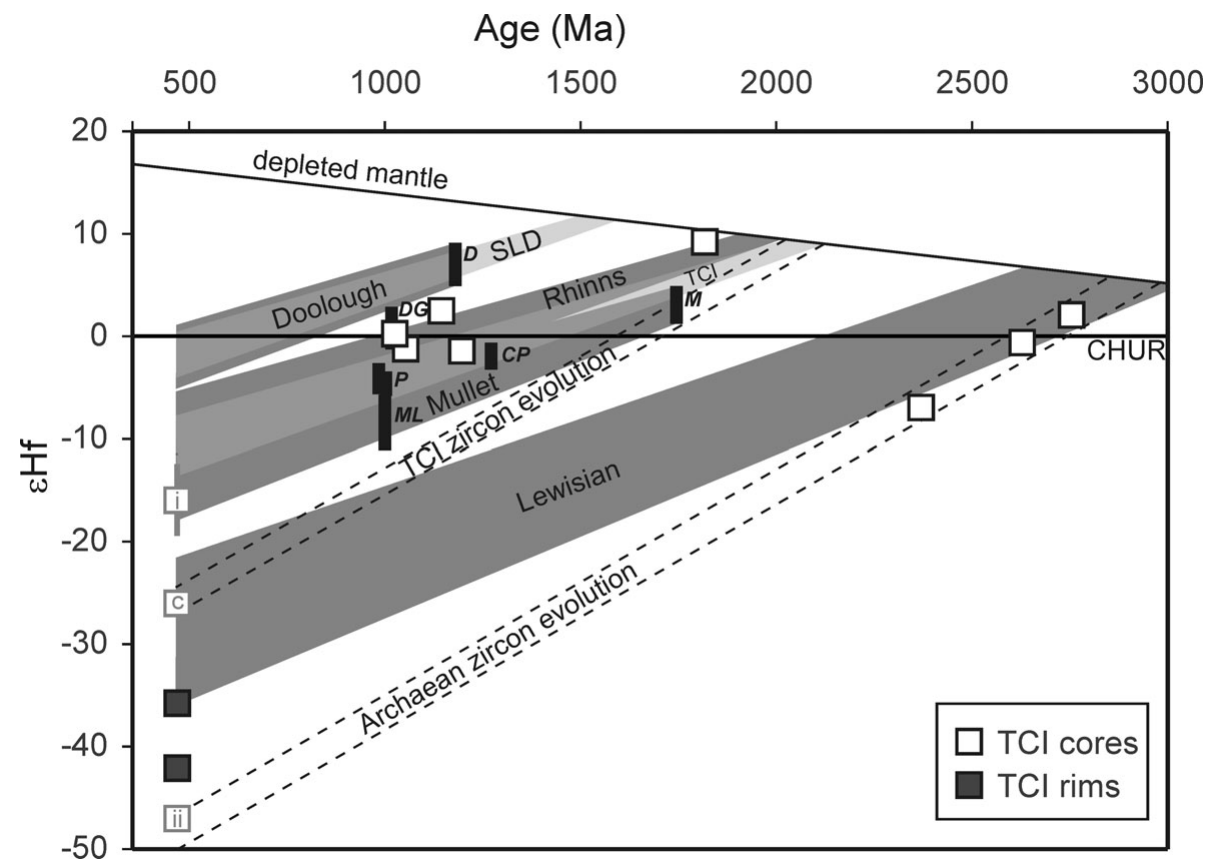

Figure 6. Age against $\varepsilon \mathrm{Hf}$ evolution plot showing the evolution fields for possible basement sources for the Tyrone Central Inlier hosted pegmatite. Labelled squares show the average core composition, 'c', itself made of two distinct populations with averages labelled ' $i$ ' and 'ii'. Whole rock evolution trends are calculated using a ${ }^{176} \mathrm{Lu} /{ }^{177} \mathrm{Hf}$ ratio $=0.015 \pm 0.002$ for the Tyrone Central Inlier and $0.011 \pm 0.002$ for the Lewisian, based on their Sm/Nd values (Chew et al. 2008; Hamilton et al. 1979; Whitehouse, 1988, 1989; Whitehouse \& Robertson, 1995). Labelled dashed lines show zircon evolution for grains with a ${ }^{176} \mathrm{Lu} /{ }^{177} \mathrm{Hf}$ ratio of 0.0016 with for the Tyrone Central Inlier and Lewisian gneisses. Abbreviations: SLD - Slishwood Division and TCI - Tyrone Central Inlier. Black bars refer to the Hf data of Daly (2009) for the Annagh Gneiss Complex, abbreviated as in Figure 5.

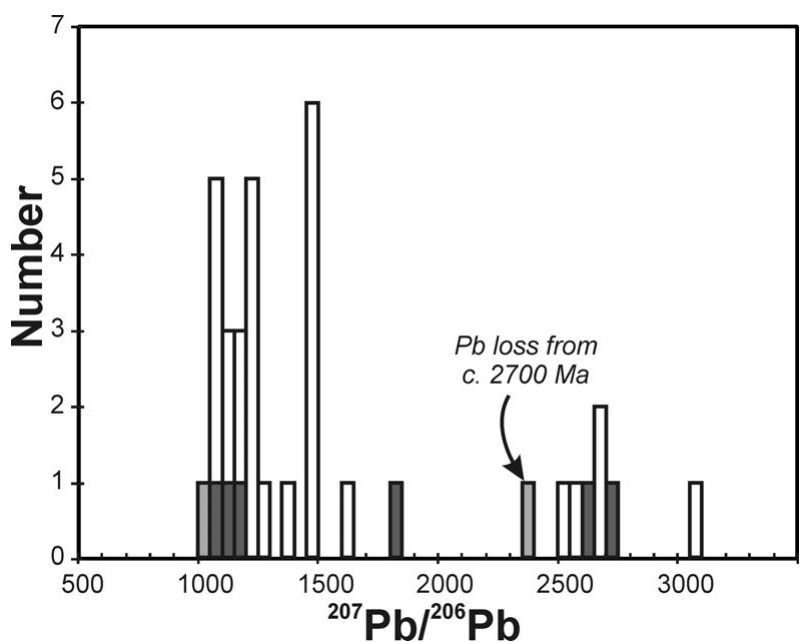

Figure 7. Histogram of ${ }^{207} \mathrm{~Pb} /{ }^{206} \mathrm{~Pb}$ detrital zircon ages for metasediments of the Tyrone Central Inlier (Chew et al. 2008) and for the inherited zircons from the intrusion cutting the Tyrone Central Inlier. Pale shading indicates inherited grains and dark shading indicates where zircons of that age occur in both the metasediment and the intrusion.

(Fig. 6). This implies that if the Lewisian was a source, zircon dissolution must also have occurred in the source region and influenced the $\mathrm{Hf}$ budget of the melt, as the rim values approach those of a typical evolved Lewisian zircon, as is indicated by line on Figure 6. These data therefore support the suggestion of Long \& McConnell (1999) that Archaean crust occurs at depth in NW Ireland. If the Lewisian was not a source, then the melt was derived from rocks with older crustal residence ages than the Lewisian. While such rocks have yet to be identified in Britain or Ireland, detrital zircons from Torridonian rocks in Scotland, which are thought to have eroded the Lewisian and contain Mesoarchaean grains (Rainbird, Hamilton \& Young, 2001), suggest that the domains of this age within the Lewisian may be present.

\section{6.d. Architecture of the Irish basement}

Major isotopic domains (corresponding to major Laurentian crustal provinces) are recognized in NW Ireland. Hf isotopic data suggest that Archaean crust lies beneath the Tyrone Central Inlier and Palaeoproterozoic crust (either Annagh Gneiss Complex or Rhinns complex) or lower Dalradian metasediments lie beneath the Slishwood Division. If the Annagh Gneiss Complex forms the crystalline basement under the Slishwood Division, then both of the two chemically distinct reservoirs (see Section 6.b.2) are likely present, with the Doolough reservoir being more significant than is apparent from the exposed Annagh Gneiss Complex. A greater proportion of Doolough-type gneiss beneath the Slishwood Division could account for its anomalous geophysical properties when compared with the rest of the Laurentian margin in Ireland.

It is not unreasonable to expect the presence of Archaean crust, given that the Lewisian Complex is not a single entity but rather a collage of Archaean and Proterozoic terranes (Kinny, Friend \& Love, 2005). 
Given that the Slishwood Division and Tyrone Central Inlier were possibly discrete and outboard elements of Laurentia, both units could have travelled laterally along the margin of Laurentia during collision with the Midland Valley Terrane. These isotopic provinces inferred in the deep crust may, therefore, represent terranes bounded by deep-seated Grampian structural lineaments.

\section{Conclusions}

Hf isotopic analyses were undertaken on magmatic and inherited zircons from $470 \mathrm{Ma}$ minor granitoid intrusions that cut allochthonous metasediments of the Slishwood Division and Tyrone Central Inlier, both located close to the Laurentian margin in NW Ireland. Major differences in the Hf isotope data are interpreted to reflect the contrasting character of the hidden crystalline basement beneath the two regions.

Magmatic zircon overgrowths from intrusions cutting the Slishwood Division yield Mesoproterozoic LuHf depleted mantle model ages, and are on average more radiogenic than the average inherited component. Magmatic zircon overgrowths from intrusions cutting the Tyrone Central Inlier yield late Archaean model ages, which are much less radiogenic than the inherited component.

The disparity between the $\mathrm{EHf}_{470}$ values of the cores and overgrowths and the internal zircon textures are interpreted to suggest that the inherited zircon component was not dissolved and did not, therefore, contribute its Hf budget to the melt. While zircon dissolution may have occurred at source, the origin for the majority of the inherited grains was probably through their incorporation into the melt during intrusion, most likely from local host country rocks.

The Hf data from the Slishwood Division zircon overgrowths suggest an Annagh Gneiss Complex or Rhinns Complex source, or sediment predominantly derived from these units, such as the lower Dalradian, and that crust of this nature is present at depth. Zircon overgrowths in the intrusion cutting the Tyrone Central Inlier require an Archaean source or sediment derived from Archaean rocks, and therefore Lewisian-type rocks are likely present at depth in Ireland.

Acknowledgements. Matt Horstwood and Vanessa Pashley are thanked for their assistance at NIGL. Grit Steinhoefel and Craig Storey are thanked for their helpful and constructive reviews.

\section{References}

AMELIN, Y. 2005. Meteorite phosphates show constant Lu176 decay rate since 4557 million years ago. Science 310, 839-41.

BAnKs, C. J., SMith, M., Winchester, J. A., Horstwood, M. S. A., Noble, S. R. \& Ottley, C. J. 2007. Provenance of intra-Rodinian basin-fills: The lower Dalradian Supergroup, Scotland. Precambrian Research 153, 46-64.
BLICHERT-TOFT, J. 2008. The Hf isotopic composition of zircon reference material 91500. Chemical Geology 253, 252-7.

Blichert-Toft, J. \& AlBarède, F. 1997. The Lu-Hf isotope geochemistry of chrondrites and the evolution of the mantle-crust system. Earth and Planetary Science Letters 148, 243-58.

Cawood, P. A., Nemchin, A. A., Smith, M. \& Loewy, S. 2003. Source of the Dalradian Supergroup constrained by $\mathrm{U}-\mathrm{Pb}$ dating of detrital zircon and implications for the East Laurentia margin. Journal of the Geological Society, London 160, 231-46.

CHEN, R.-X., ZHENG, Y.-F., ZHAO, Z.-F., TANG, J., WU, F.-Y. \& LIU, X. M. 2007. Zircon U-Pb age and Hf isotope evidence for contrasting origin of bimodal protoliths for ultrahigh-pressure metamorphic rocks from the Chinese Continental Scientific Drilling project. Journal of Metamorphic Geology 25, 873-94.

Chew, D. M., Flowerdew, M. J., Page, L. M., Crowley, Q. G., DALY, J. S., COOPER, M. \& Whitehouse, M. J. 2008. The tectonothermal evolution and provenance of the Tyrone Central Inlier, Ireland: Grampian imbrication of an outboard Laurentian microcontinent? Journal of the Geological Society, London 165, 675-85.

Chew, D. M., Graham, J. R. \& Whitehouse, M. J. 2007. U-Pb zircon geochronology of plagiogranites from the Lough Nafooey (= Midland Valley) arc in western Ireland: constraints on the onset of the Grampian orogeny. Journal of the Geological Society, London 164, 747-50.

Chew, D. M. \& Schaltegger, U. 2005. Constraining sinistral shearing in NW Ireland: a precise $\mathrm{U}-\mathrm{Pb}$ zircon crystallisation age for the Ox Mountains Granodiorite. Irish Journal of Earth Sciences 23, 55-63.

Clemens, J. D. 2003. S-type granitic magmas - petrogenetic issues, models and evidence. Earth Science Reviews 61, $1-18$.

CoOper, M. R., Crowley, Q. G. \& Rushton, A. W. A. 2008. New age constraints for the Ordovician Tyrone Volcanic Group, Northern Ireland. Journal of the Geological Society, London 165, 333-9.

DALY, J. S. 2009. Precambrian. In The Geology of Ireland, 2nd edition (eds C. H. Holland \& I. S. Sanders), pp. 7-42. Edinburgh: Dunedin Academic Press.

DALY, J. S. 1996. Pre-Caledonian history of the Annagh Gneiss Complex, northwestern Ireland, and correlation with Laurentia-Baltica. Irish Journal of Earth Sciences 15, 5-18.

DALY, J. S. \& FlOWERDEW, M. J. 2005. Grampian and lateGrenville events recorded by mineral geochronology near a basement-cover contact in N. Mayo, Ireland. Journal of the Geological Society, London 162, 16374.

DALY, J. S. \& MENUGE, J. F. 1989. Nd-isotopic evidence for the provenance of the Dalradian Supergroup sediments in Ireland. Terra Abstracts 1, 12.

DALY, J. S., MuIR, R. J. \& CLIFF, R. A. 1991. A precise U-Pb zircon age for the Inishtrahull syenitic gneiss, County Donegal, Ireland. Journal of the Geological Society, London 148, 639-42.

Dempsey, C. S., Halliday, A. N. \& Meighan, I. G. 1990. Combined $\mathrm{Sm}-\mathrm{Nd}$ and $\mathrm{Rb}-\mathrm{Sr}$ isotope systematics in the Donegal granitoids and their petrogenetic implications. Geological Magazine 127, 75-80.

Dickin, A. P. \& BowES, D. R. 1991. Isotopic evidence for the extent of early Proterozoic basement in Scotland and northwest Ireland. Geological Magazine 128, 3858 . 
Draut, A. E., Clift, P. D., Chew, D. M., Cooper, M. J., TAYLOR, R. N. \& HANNIGAN, R. E. 2004. Laurentian crustal recycling in the Ordovician Grampian Orogeny: $\mathrm{Nd}$ isotopic evidence from western Ireland. Geological Magazine 141, 195-207.

FLOWERDEW, M. J. \& DALY, J. S. 2005. Sm-Nd mineral ages and $\mathrm{P}-\mathrm{T}$ constraints on the pre-Grampian high grade metamorphism of the Slishwood Division, north-west Ireland. Irish Journal of Earth Sciences 23, 107-23.

Flowerdew, M. J., Daly, J. S., Guise, P. G. \& Page, L. M. 2000. The Slishwood Division and its role in the Grampian Orogeny-Indenter tectonics in the Caledonides of Ireland. Irish Journal of Earth Sciences 18, 132-3.

Flowerdew, M. J., DALY, J. S. \& Whitehouse, M. J. 2005. 470 Ma granitoid magmatism associated with the Grampian Orogeny in the Slishwood Division, NW Ireland. Journal of the Geological Society, London 162, 563-75.

Flowerdew, M. J., Millar, I. L., Vaughan, A. P. M., Horstwood, M. S. A. \& FAnNING, C. M. 2006. The source of granitic gneisses and migmatites in the Antarctic Peninsula: a combined U-Pb SHRIMP and laser ablation $\mathrm{Hf}$ isotope study of complex zircons. Contributions to Mineralogy and Petrology 151, 751-68.

Griffin, W. L., Belousova, E. A., Shee, S. R., Pearson, N. J. \& O'REILlY, S. Y. 2004. Archean crustal evolution in the northern Yilgarn Craton: U-Pb and Hf-isotope evidence from detrital zircons. Precambrian Research 131, 231-82.

Griffin, W. L., Pearson, N. J., Belousova, E. A. \& SAeEd, A. 2006. Comment: Hf-isotope heterogeneity in zircon 91500. Chemical Geology 233, 358-63.

Halliday, A. N., Dickin, A. P., Hunter, R. N., Davies, G. R., Dempster, T. J., HAMilton, P. J. \& UptON, B. G. J. 1993. Formation and composition of the lower continental crust: evidence from Scottish xenolith suites. Journal of Geophysical Research 98B, 581-607.

HAMILTON, P. J., EVENSEN, N. M., O’NIONS, R. K. \& TARNEY, J. 1979. Sm-Nd systematics of Lewisian gneisses implications for origin of granulites. Nature 277, 25 8.

HARTLEY, J. J. 1933. The geology of north-eastern Tyrone and the adjacent portions of County Londonderry. Proceedings of the Royal Irish Academy 41B, 218-85.

HiBBARD, J., TRACY, R. \& HENIKA, W. 2003. The Smith River allochthon: a southern Appalachian peri-Gondwana terrane emplaced directly on Laurentia? Geology $\mathbf{3 1}$, 215-18.

Hoskin, P. W. O., Kinny, P. D., Wyborn, D. \& Chappel, B. W. 2000. Identifying accessory mineral saturation during differentiation in granitoid magmas: an integrated approach. Journal of Petrology 41, 1365-96.

KinNY, P. D., Friend, C. R. L. \& Love, G. J. 2005. Proposal for a terrane-based nomenclature for the Lewisian Gneiss Complex of NW Scotland. Journal of the Geological Society, London 162, 175-86.

LANDES, M., RITTER, J. R. R., READMAN, P. W. \& O'REILLY, B. M. 2005. A review of the Irish crustal structure and signatures from the Caledonian and Variscan Orogenies. Terra Nova 17, 111-20.

Loewy, S. L., ConNelly, J. N., DAlziel, I. W. D. \& Gower, C. F. 2003. Eastern Laurentia in Rodinia: constraints from whole-rock $\mathrm{Pb}$ and $\mathrm{U} / \mathrm{Pb}$ geochronology. Tectonophysics 375, 169-97.

Long, C. B. \& MCCONNELl, B. J. 1999. Geology of South Donegal: A geological description to accompany the bedrock geology 1:100,000 scale map series, sheet 3 and part of sheet 4, South Donegal. With contributions from G. I. Alsop, P. O'Connor, K. Claringbold, and C. Cronin. Geological Survey of Ireland, $116 \mathrm{pp}$.

LOWE, C. \& JACOB, A. W. B. 1989. A north south seismic profile across the Caledonian suture zone in Ireland. Tectonophysics 168, 297-318.

Marcantonio, F., Dickin, A. P., MCNutt, R. H. \& HEaman, L. M. 1988. A 1,800-million-year-old Proterozoic gneiss terrane in Islay with implications for the crustal structure and evolution of Britain. Nature 335, 62-4.

MAX, M. D. \& LonG, C. B. 1985. Pre-Caledonian basement in Ireland and its cover relationships. Geological Journal 20, 341-66.

MaX, M. D. \& RidDihough, R. P. 1975. Continuation of the Highland Boundary Fault in Ireland. Geology 10 206-10.

Menuge, J. F. \& Daly, J. S. 1990. Proterozoic evolution of the Erris Complex, NW Mayo, Ireland: neodymium isotope evidence. In Mid Proterozoic Laurentia-Baltica (eds C. F. Gower, T. Rivers \& B. Ryan), pp. 41-52. Geological Association of Canada, Special Paper no. 38.

Muir, R. J., Fitches, W. R. \& Maltman, A. J. 1994. The Rhinns Complex: Proterozoic basement on Islay and Colonsay, Inner Hebrides, Scotland, and on Inishtrahull, NW Ireland. Transactions of the Royal Society of Edinburgh: Earth Sciences 85, 77-90.

Muir, R. J., Fitches, W. R. \& Maltman, A. J. 1995. The Colonsay Group and basement-cover relationships on the Rhinns of Islay, Inner Hebrides. Scottish Journal of Geology 31, 1-6.

Pidgeon, R. T. \& Compston, W. 1992. A SHRIMP ion microprobe study of inherited and magmatic zircons from 4 Scottish Caledonian granites. Transactions of the Royal Society Edinburgh: Earth Sciences 83, 473-83.

PowELL, D. 1965. Comparison of calc-silicate bands from the Moine schists of Inverness-shire with similar bands from Moine-like rocks in Donegal. Nature 206, 180-1.

RAINBIRD, R. H., HAMILTON, M. A. \& YounG, G. M. 2001. Detrital zircon geochronology and provenance of the Torridonian, NW Scotland. Journal of the Geological Society, London 158, 15-27.

Readman, P. W., O’Reilly, B. M. \& Murphy, T. 1997. Gravity gradients and upper crustal tectonic fabrics, Ireland. Journal of the Geological Society, London 154, 817-28.

RoDDICK, J. C. \& MAX, M. D. 1975. A Laxfordian age from the Inishtrahull platform, County Donegal, Ireland. Scottish Journal of Geology 19, 97-102.

RYAN, P. D., SOPER, N. J., SNYDER, D. B., ENGLAND, R. W. \& HutTON, D. H. W. 1995. The Antrim-Galway Line: a resolution of the Highland Border Fault enigma of the Caledonides of Britain and Ireland. Geological Magazine 132, 171-84.

SANDERS, I. S. 1994. The northeast Ox Mountains inlier, Ireland. In A Revised Correlation of Precambrian rocks in Britain and Ireland (eds W. Gibbons \& A. L. Harris), pp. 63-4. Geological Society of London, Special Report no. 22.

SANDERS, I. S., DALY, J. S. \& DAVIES, G. R. 1987. Late Proterozoic high-pressure granulite facies metamorphism in the north-east Ox inlier, north-west Ireland. Journal of Metamorphic Geology 5, 69-85.

SCHERER, E., MÜNKER, C. \& MEZGER, K. 2001. Calibration of the lutetium hafnium clock. Science 293, 683-7.

SNYDER, D. B., ENGLAND, R. W. \& MCBRIDE, J. H. 1997. Linkage between mantle and crustal structures and its 
bearing on inherited structures in northwestern Scotland. Journal of the Geological Society, London 154, 79-83.

Steinhoefel, G., Hegner, E. \& Oliver, G. J. H. 2008. Chemical and $\mathrm{Nd}$ constraints on granitoid sources involved in the Caledonian Orogeny in Scotland. Journal of the Geological Society, London 165, 817-27.

THIRLWALL, M. F. \& ANCZKIEWICZ, R. 2004. Multidynamic isotope ratio analysis using MC-ICP-MS and the causes of secular drift in $\mathrm{Hf}, \mathrm{Nd}$ and $\mathrm{Pb}$ isotope ratios. International Journal of Mass Spectrometry 235, 5981.

ThirlWall, M. F. \& WALDER, A. J. 1995. In situ hafnium isotope ratio analysis of zircon by inductively coupled plasma multiple collector mass spectrometry. Chemical Geology 122, 241-7.

Tyrrell, S., Haughton, P. D. W. \& Daly, J. S. 2007. Drainage re-organisation during break-up of Pangea revealed by in-situ $\mathrm{Pb}$ isotopic analysis of detrital $\mathrm{K}$ feldspar. Geology 35, 971-4.

Van StaAl, C. R., Dewey, J. F., Mac Niocaill, C. \& MCKerRow, W. S. 1998. The Cambrian-Silurian tectonic evolution of the northern Appalachians and British Caledonides: history of a complex, west and southwest Pacific-style segment of Iapetus. In Lyell: the past is the key to the present (eds D. J. Blundell \& A. C. Scott), pp. 199-242. Geological Society of London, Special Publication no. 143.

VervoORT, J. D. \& PATCHETT, P. J. 1996. Behavior of hafnium and neodymium isotopes in the crust: Constraints from Precambrian crustally derived granites. Geochimica et Cosmochimica Acta 60, 3717-33.

Warner, M., Morgan, J., Barton, P., Morgan, P., Price, C. \& JONES, K. 1996. Seismic reflections from the mantle represent relict subduction zones within the continental lithosphere. Geology 24, 39-42.

Whitehouse, M. J. 1988. Granulite facies Nd-isotopic homogenization in the Lewisian complex of northwest Scotland. Nature 331, 705-7.

WhiteHouse, M. J. 1989. Sm-Nd evidence for diachronous crustal accretion in the Lewisian Complex of northwest Scotland. Tectonophysics 161, 245-56.

Whitehouse, M. J. \& RoBerTSON, C. J. 1995. Isotopic evolution of the Lewisian complex of Tiree, Inner
Hebrides and correlation with the mainland. Scottish Journal of Geology 31, 131-7.

Wiedenbeck, M., Alle, P., Corfu, F., Griffin, W. L., MeIrer, M., Oberli, F., Von QuAdt, A., Roddick, J. C. \& SPIEGEL, W. 1995. Three natural zircon standards for $\mathrm{U}-\mathrm{Th}-\mathrm{Pb}, \mathrm{Lu}-\mathrm{Hf}$, trace element and REE analyses. Geostandards Newsletter 19, 1-23.

WILliAMS, I. S. 2001. Response of detrital zircon and monazite, and their $\mathrm{U}-\mathrm{Pb}$ isotopic systems, to regional metamorphism and host-rock partial melting, Cooma Complex, southeastern Australia. Australian Journal of Earth Sciences 48, 557-80.

Woodhead, J., Hergt, J., SHElley, M., EgGins, S. \& KeMP, R. 2004. Zircon Hf-isotope analysis with an excimer laser, depth profiling, ablation of complex geometries, and concomitant age estimation. Chemical Geology 209, 121-35.

Wu, F.-Y., YANG, Y.-H., XIE, L.-W., YANG, J.-H. \& XU, P. 2006. Hf isotopic compositions of the standard zircons and baddeleyites used in $\mathrm{U}-\mathrm{Pb}$ geochronology. Chemical Geology 234, 105-26.

WU, Y.-B., ZHENG, Y.-F., ZHANG, S.-B., ZHAO, Z.-F., WU, F.-Y. \& LIU, X.-M. 2007. Zircon U-Pb ages and Hf isotope compositions of migmatite from the North Dabie terrane in China: constraints on partial melting. Journal of Metamorphic Geology 25, 991-1009.

YANG, J.-H., WU, F.-Y., WILDE, S. A., XIE, L.-W., YANG, Y.-H., \& LIU, X.-M. 2007. Tracing magma mixing in granite genesis: in situ $\mathrm{U}-\mathrm{Pb}$ dating and Hf-isotope analysis of zircons. Contributions to Mineralogy and Petrology 153, 177-90.

Zeh, A., Gerdes, A., Klemd, R. \& Barton, J. M. 2007. Archaean to Proterozoic Crustal evolution in the Central Zone of the Limpopo Belt (South Africa-Botswana): Constraints from combined $\mathrm{U}-\mathrm{Pb}$ and $\mathrm{Lu}-\mathrm{Hf}$ isotope analyses of zircon. Journal of Petrology 48, 160539.

ZHENG, Y.-F., WU, Y.-B., ZHAO, Z.-F., ZhANG, S.-B., XU, P. \& WU, F.-Y. 2005. Metamorphic effect on zircon $\mathrm{Lu}-\mathrm{Hf}$ and $\mathrm{U}-\mathrm{Pb}$ isotope systems in ultrahighpressure eclogite-facies metagranite and metabasite. Earth and Planetary Science Letters 240, 378400 . 